\title{
AN ANALYSIS OF THE BRITISH INVASION OF EGYPT (1882) THROUGH THE LENS OF VICTORIAN PARTY POLITICS
}

\author{
Begüm Y1ldızeli \\ Dr. Öğr. Üyesi, Bilecik Şeyh Edebali Üniversitesi, İktisadi ve İdari Bilimler Fakültesi, \\ Uluslararası İlişkiler Bölümü, Bilecik, Türkiye
}

\begin{abstract}
The British occupation of Egypt in 1882 meant a breakaway from the Anglo-French entente's control over Ottoman financial system and the end of the Liberal Government's 'reluctant' imperialism. When the Liberal ministry began in 1880, the cabinet immediately focused on foreign policies towards the Ottoman Empire subsequent to Gladstone's campaign during the Bulgarian Agitation which had already turned out to be a party question. The protection of the Suez Canal as well as the interests of the British bondholders and the prestige of the British Empire was vital, which united the Liberal ministry and the Conservatives under the same purpose. Despite late Ottoman approval, the occupation signified the edge of Anglo-Ottoman alliance during the nineteenth century. This study will analyse why the Egyptian question is important for British party politics and to what extend the Anglo-Ottoman relations was affected with these circumstances.
\end{abstract}

Keywords: Suez Canal, British Party Politics, Egypt, Urabi Pasha

Öz

\section{VIKTORYA DÖNEMI PARTI SIYYASETI PERSPEKTIFINNDEN INGILIZLER'İN MISIR'I IŞGALI (1882) ÜZERINE BIR ANALIZ}

1882 yılında İngilizler 'in Mısır'ı işgali gerek İngiliz Hükümeti'nin 'gönülsüz' emperyalizminin gerekse de Osmanlı ekonomisindeki İngiliz -Fransız kontrolünün sonu anlamına gelmekteydi. 1880 yılında Liberal parti göreve baslar başlamaz, William E. Gladstone'un 1876 yılında gerçekleştirdiği Bulgar Ajitasyonu kampanyasının bir devamı olan ve parti siyasetinde ana gündem maddesini

Sorumlu yazar/ Corresponding author: Begüm Yıldızeli, begum.yildizeli@bilecik.edu.tr, begumyildizeli@gmail.com

Geliş Tarihi/Submitted: 17.10.2018 Kabul Tarihi/Accepted: 22.05.2019

DOI: 10.26650 /TurkJHist.2019.18010

Cite this article as: Yıldızeli, Begüm, "An Analysis of The British Invasion of Egypt (1882) Through the Lens of Viictorian Party Politics”, Turk J Hist, issue 69 (2019), p.113-134. 
oluşturmuş Osmanlı İmparatorluğu'na yönelik dış politikaya ağırlık vermişlerdi. Süveyş Kanalı'nın korunması, İngiliz tahvil sahiplerinin çıkarları ve İngiliz İmparatorluğu'nun prestiji bu açıdan Liberal ve Muhafazakârları ayni amaçta birleştirmişti. Osmanlı'nın geç onayıyla, 19. yüzyıl boyunca suren Osmanlı-İngiliz İşbirliği'nde işgal köşe taşlarından biri olmuştur. Bu çalışma, Mısır Sorunu'nun İngiliz parti politikasında önemi ve Osmanl-İngiliz ilişkilerini bu şartlar altında ne derecede etkilediğini analiz edecektir.

Anahtar Kelimeler: Süveyş Kanalı, İngiliz Parti Politikası, Mısır, Urabi Pasa

\section{Introduction}

In 1571, Egypt had become a state under Ottoman rule led by Sultan Selim I, also known as the Selim the Grim, at the height of his power. In addition to its strategic and economic contributions to the empire, the Ottoman Empire became the most powerful state in the Islamic world as the main defender of the Holy lands by gaining the position of Caliphate as a result of the conquest of Egypt. Notwithstanding, it is fair to state that the protection of political stability in Egypt had been extremely troublesome for the Ottoman Empire due to its geographical distance from the Porte and the conflicting interests of local governors. By the end of the eighteenth century, however, it can be argued that external circumstances played a more profound role in the affairs of Ottoman Egypt. In that respect, Anglo-French rivalry on the supremacy of African dominions and the Russian policy of Panslavism in the Ottoman provinces can be counted as the two most significant aspects. There is little doubt that the French occupation of Egypt led by Napoleon Bonaparte I in 1798 was not welcomed by the Ottoman Empire, but particularly not by Great Britain. As the French evacuation from Egypt was beyond the Ottoman military power, the occupation eased British aid to the Ottoman Empire. ${ }^{1}$ Ultimately, however, this aid can be seen as a milestone of the Anglo-Ottoman alliance during the nineteenth century, which would last until the Russo-Ottoman War of 1877-1878 and ended up with the British occupation of Egypt in 1882.

It can further be argued that the political unrest in Egypt strengthened the Anglo-Ottoman alliance and British party politics gradually began to merge with the Ottoman domestic affairs. The revolt of Mehmet Ali Pasha of Egypt in 1831 and the Hunkar Iskesi Treaty (1838) which allowed privileges to Russia on the Straits also enhanced British interests in the Ottoman Empire. Despite the intimacy between Russia, the trade agreement with Great Britain on 1838 was remarkable for the course of diplomatic and economic relations. Along with the treaty, British

1 For further information on the French Occupation of Egypt (1798-1801), see Kamil Colak, 'Misir'in Fransizlar tarafinda isgali ve tahliyesi' 'The Occupation and Evacuation of Egypt by the French', SAU Fen-Edebiyat Dergisi, (2008-II), pp. 141-183. 
merchants gained trade privileges in the Ottoman market. ${ }^{2}$ Zeytinli states with the free trade agreement, export of Ottoman goods to Great Britain increased $6.8 \%$ per year between 1838 and $1854 .^{3}$ More to the point, Kocaoglu emphasises that Britain prevented Mehmet Ali Pasha from becoming stronger, secured Britain's interests and safeguarded the Eastern Mediterranean with India and witnessed how 'valuable Egypt was for the higher British interests.' 4 In order to secure the settlement in Egypt with an international commitment, the London Convention for the Pacification of the Levant signed between the Ottoman Empire and Russia, Great Britain, Austria, Prussia on 15 July 1840. Prior to this treaty, Queen Victoria had already declared that she sided with the territorial integrity and independence of the Ottoman Empire. In a question raised by Robert Peel with regards to the Queen's speech at the opening of the session, on the persistence of the unity, Lord Palmerston as the foreign secretary assured that, '... these powers had been unanimous in preserving peace in that quarter.' 5

Following the proclamation of Tanzimat in 1839, Ata emphasises Palmerston's letter to Ponsonby by stating 'Hatt-i Serif is a major success of yours' which revealed the British influence on the Ottoman reformation era. ${ }^{6}$ Anick further argues that Palmerston himself embraced the idea that Ponsonby had asserted British supremacy 'more firmly at Constantinople than it ever was established before' and 'Ponsonby's successors, including Stratford, were able to maintain until the end of the century what Ponsonby had established.' ${ }^{7}$ Furthermore, there is little doubt that Stratford Canning's ambassadorship as the Great Elchi ${ }^{8}$ at Constantinople between 1841 and 1856 together with Lord Palmerston's preservationist policies ${ }^{9}$ re-

2 Hansard Parliamentary Debates House of Commons (HC hereafter) HC Deb 06 August 1839 vol 49 cc1388-98, 'Trade with Turkey'.

3 Emine Zeytinli, 'The Effect of Trade Agreements: the case of international trade of Europe and Turkey', Economics and Management, 2012: pp. 1627-1636, p. 1630.

4 Mehmet Kocaoglu, 'Cavallan Mehmet Ali Pasha 1831-1841', Ankara Üniversitesi Osmanlı Tarihi Araştırma ve Uygulama Merkezi Dergisi: pp. 209-226, p. 223.

5 HC Deb 21 February 1840 vol 52 cc $445-8$, 'Affairs of Turkey'

6 Ramazan Ata, 'Osmanli kaynaklarina gore 1839-1841 arasi Osmanli-Misir iliskileri ve Duvel-i Muvazzama', 1839-1841 Ottoman Empire and Egypt Affairs and Great Powers under the Light of Ottomans' Sources', Unpublished PhD Thesis, Ankara University, Ankara 2011, p. 95.

7 Norman Anick, 'The Embassy of Lord Ponsonby to Constantinople 1833-1841', Unpublished PhD Thesis, Montreal University, Canada 1970, p. 318.

8 Lane Poole told the story of his affiliation that, "It was during his long reign at the Porte of this century $\left(19^{\text {th }}\right)$ that Canning displayed those qualities and acquired that influence that which gained him "Great Elchi." Lane-Poole, Viscount Stratford De Redcliffe, vol. II, p. 54 also see for his major influence period on Tanzimat period, Edward Ingram (ed.), Eastern Questions in the Nineteenth Century collected essays by Allan Cunningham, vol. II, Frank Cass Co. Lmtd. Publishers, Great Britain 1993, pp. 108-216

9 "I have no hesitation in saying, that it was of the utmost importance for the interest of England, and for the maintenance of the peace of Europe, that the Ottoman empire should remain entire, and be an independent State." HC Deb 11 July 1833 vol 19 cc570-83. 'Russia and Turkey' 
inforced the Anglo-Ottoman alliance. More to the point, the Crimean War provided testimonial evidence of this cooperation. Nonetheless, it is fair to state that Lord Palmerston's legacy for the Ottoman Empire remained until Gladstone's Bulgarian Agitation pamphlet in 1876.

This study aims to contribute towards a greater measure of understanding of the principles of British foreign policy decisions at the imperial level in the case of Egypt and proposes a transnational approach to the nineteenth century Anglo-Ottoman relations by wide political and economic employment. Party-political considerations and motives behind the invasion of Egypt will not only provide the reasons for 'the final turn' from the Anglo-Ottoman alliance but also reaffirm that the rivalry between Benjamin Disraeli and William Gladstone over the internal dynamism of the Eastern Question that played a key role in the determination of British imperialism. By both balancing and associating party politics and British foreign policies of the Ottoman Empire in light of a critical examination of Gladstone's Liberal government, this study will give a general assessment of how relations were adversely affected by the Eastern Question in Victorian Britain.

In order to obtain factors that shaped Britain's decision to invade Egypt, this research will explore historiography that outlines historians' exclusive claims to realistic representation. Furthermore, this study will seek to find possible answers as to the questions: what were the reasons behind Gladstone's role in British diplomacy against the Ottoman Empire; to what extent domestic politics affect foreign policy decision making and while the situation of the national politics is in suspense, what were the external factors that were profound in the decision mechanism of foreign policy? Where was Egypt in Disraeli's foreign policy agenda? How did public opinion affect the decision of British occupation of Egypt? This article will approach these questions by focusing on the events and key players that will provide a precise description. This methodology built on British parliamentary collections, newspaper articles, Gladstone's personal diary accounts and the political correspondence between Gladstone and Lord Granville.

The first part of the study is mainly concerned with the dynamics of British policy towards the Porte, a brief history of Ottoman Egypt with a detailed analysis of the British government's purchase of the Suez Canal shares. The aim of the subsequent parts of this research, namely 'Setting the party agenda and public opinion: Occupation of Egypt' is to examine and critically explore the estimation of Liberal ministry and Gladstone's further roles and impact of general attitudes of public opinion on the foreign policy decision mechanism. The following parts will, hence, consider how British policy towards the Porte under Gladstone and Lord Granville had changed which began to further push an agenda that was informed by humanitarian and moral objectives along with the vision for European 
order of nations established with international law in the 1880s in the case of Egypt.

The following part of this study will examine the key components imperialist principles of the liberal British government and what circumstances had changed since the Near-Eastern Crisis that paved the way for the transition between protecting the Ottoman territories to invade Egypt.

\section{British policy towards the Sublime Porte}

Beyond question, it was Disraeli who maintained Palmerston's legacy in the Porte. Even he, himself had stated in a letter to Lady Bradford, 'the Eastern Question, that has haunted Europe for a century, and which I thought the Crimean War had adjourned for half another, will fall to my lot to encounter-dare I say to settle?'10 Indeed, Disraeli's second premiership began with dealing with the Khedive's bankruptcy and went on to be involved in the Suez Canal Shares with France. Since the opening of the Suez Canal in 1869, Disraeli had laid the vitality of the shares for imperial attachment to India despite French domination of the Suez Canal Company. Therefore, Dennis describes the British government's purchase of the shares from the Khedive as the 'spinal cord' of the empire based on the 'inspiration of Disraeli.' 11 In its quiet intimacy, the Queen was also satisfied with Disraeli's policy in Egypt, 'I have agreed to purchase, subject to your sanction, the shares which belonged to the Khedive of Egypt in the Suez Canal, and I rely with confidence on your enabling me to complete a transaction in which the public interests are deeply involved.' ${ }^{\prime 2}$ Nonetheless, it is fair to state that there was no consensus within the British Parliament as to the forthcoming movements in Egypt. It is beyond any question that Disraeli's second premiership in 1874 began with dealing the Khedive's bankrupts and eventually involving in the Suez Canal Shares with France. Nonetheless, it is fair to state that there was no consensus within the British Parliament as to the forthcoming movements in Egypt. By referring to Gladstone's premiership between 1868 and 1874 Disraeli claimed that 'It has shown, in a manner about which neither the House of Commons nor the country can make any mistake, that had the right honourable Gentleman the Member for Greenwich (Mr. Gladstone) been the Prime Minister of this country, the shares in the Suez Canal would not have been purchased. The right hon. Gentleman, in his numerous observations upon the Vote before the House, has divided them under two heads - what he calls the operation and the policy.' ${ }^{13}$ By

10 'Disraeli to Lady Bradford', 3 November 1875 quoted in Seton Watson, R. W., Disraeli, Gladstone and the Eastern Question: A Study in Diplomacy and Party Politics, Macmillan, London 1936, p. 26.

11 Alfred L. P. Dennis, 'Tendencies in British policy since Disraeli', Proceedings of the American Political Science Association, Vol. 6, Sixth Annual Meeting (1909), pp. 109-120, p. 110.

12 HL Deb 08 February 1876 vol 227 cc1-6, 'The Queen's speech'

13 HC Deb 21 February 1876 vol 227 cc562-661'Supply- $£ 4.080 .000$ Suez Canal Shares-Adjourned 
the same token, Gladstone occasionally opposed Disraeli's vote for the $£ 4 \mathrm{~m}$ for the shares of the Khedive, criticised the ground of the proposals and the treatment of the Suez Canal Company with France. ${ }^{14}$

Beside the parameters British party politics, Anglo-French relations over Egypt should also be considered. Newman argues that 'France was in favour of a favoured loosening of the 'ties which bound Egypt to Turkey', while Great Britain was in tendency to 'oppose any measures tending to break up the Ottoman Empire. ${ }^{15}$ More to the point, the Dual Control on the Suez Canal discreetly lasted until 1882 due to the clash of the economic interests of the countries, transformation in British party politics and French invasion of Tunisia in 1881. Beyond Anglo-French competition, Atkins further points out 'the new administrative apparatus was expensive, the establishment of well-paid incompetents due to nepotism and relentless tax pressures which was the foundation of Urabi (Arabi) Pasha rebellion in 1882. ${ }^{16}$

While the historical facts and the assumptions on which the British policy has rested gives a general picture up until 1882, the subsequent part of this research should evaluate with the economic and political aspects of the British invasion of Egypt and how it has been applied to national politics. Before the invasion of Egypt, the British were attracted to the imperialist ambitions on the Ottoman lands, and the next steps were taken harder.

Setting the party agenda and public opinion: Occupation of Egypt (1882)

On this basis, it has been further argued that Gladstone's main task as Prime Minister was now to reverse Disraeli's pro-Turkish foreign policies. Within limits, the boundaries of British foreign policies were mainly confined to the idea of 'the Concert of Europe' and assuring Turkish sovereignty over her territories which meant a purely territorial integrity from Gladstone's perspective. ${ }^{17}$ Nonetheless, safeguarding and allying with the Turks was controversial since the annexation of Cyprus and the future of relations was seriously fragile. More to the point, the consideration of Abdulhamid II also became the farther aspect for the course of Anglo-Ottoman relations whose fundamental reign started in 1881 after the experience the Sultan had during the Bulgarian Agitation. On the other hand, the policy that Gladstone had pursued against the imperialist principles of the Disraeli cabinet during his period of opposition was turned into a major controversy in terms of

Debate

14 Ibid.

15 Polson E. W. Newman, Great Britain in Egypt, Cassell and Company Limited, London 1928, p. 84.

16 Richard Atkins, 'The Origins of the Anglo-French Condonium in Egypt, 1875-1876', The Historian, pp. 264-282, p. 282.

17 Agatha Ramm (ed) The political correspondence of Mr. Gladstone and Lord Granville 18761886, Volume I, 1876-82, Clarendon Press, Oxford 1962, p. 291. 
his goals for Egypt as Prime Minister. Arguably, it was again his responsibility to compose more conducive principles for the expedience of British imperialism and Gladstonian liberalism. Nonetheless, it is clear that it was troublesome for him to regulate this balance between his thoughts in opposition as a private citizen and his actions as the head of the government. In a letter to Jewish journalist A. I. Myers' based on the accounts of 'Persecution of the Jews in Russia in 1881' on 18 January 1882; he referred his appeal saying that, 'to make an appeal not to Governments, not even to my countrymen specifically or alone, but to the civilised nations of Christendom through the press. ${ }^{18}$ By addressing his policy during the Bulgarian Agitation, Matthew had already highlighted, indeed, a composition between the 'equal rights of all nations' and the essentials of international order was 'a highly problematic duty for the Liberal Prime Minister of an imperial Power. ${ }^{19}$ Aside from the consequences for British imperialism and liberalism, it is argued that the result of the occupation for the course of the Anglo-Ottoman relations was substantially neglected in the scholarship.

There is a clear sense that there no unanimous decision between historians as to the reasons for the British occupation of Egypt. Conversely, it would also be fair to state that there is no clear distinction between the period living historians such as Milner, Hobson with Blunt and contemporary scholars Robinson \& Gallagher, Hopkins, Galbraith \& Sayyid-Marsot with regards to the foundation of British imperialism in Egypt. Arguably, each school of thought is based upon the entailment of the invasion for the welfare and honour of the British Empire. Nonetheless, their arguments as to the legitimate justifications may still be classified between economic and social rationality. From the economic point of view, Robinson and Gallagher argue that the core aspect of British expansion was 'a symbiosis' between her trade and her power in India throughout the nineteenth century. ${ }^{20}$ Hobson also underlines both the financial stake of the bondholders and their political influence in Egypt. ${ }^{21}$ By supporting this argument Hopkins addresses Blunt and Hobson's approach as 'the tradition' deserved 'attention not only because it had made an important contribution to the intellectual history but also had exerted a powerful influence on current on new imperialistic motives of Britain in the Middle East and empire-building approaches in general' subsequent to the occupation of Egypt. ${ }^{22}$ Besides, there is

18 H. C. G., Matthew, (ed.) The Gladstone Diaries, vol. X, Clarendon Press, Oxford 1990, p. 198

19 Colin H. G. Matthew, Gladstone 1875-1898, Clarendon Press, Oxford 1995, p. 124.

20 Ronald Robinson and John Gallagher, Africa and the Victorians the Official Mind of Imperialism, Macmillan\& Co. Lmtd., London 1965, p. 11.

21 John A. Hobson, Imperialism: A study, James Nisbet \& Co. Limited, London 1902, p. 210; Wilfred S. Blunt, A Secret History of the British Occupation of Egypt, London, 1907, p. 199 cited in A. G. Hopkins, 'The Victorians and Africa: A reconsideration of the Occupation of Egypt, 1882', Journal of African History, 27, (1986), pp. 363-391, p. 366.

22 Ibid, p. 367. 
little doubt that ensuring British interests in the Suez Canal was vital for the British Empire to protect the routes to India. In 1875 the French Government refused to interfere, the French association fell through raising the money, and the Khedive committed to sell his shares to the British Government for $£ 4 \mathrm{~m}$ on November $23 .{ }^{23}$ In a similar vein, prior to the invasion, however, Galbraith and Marsot argue that 'the security of the canal' was justification for the occupation of Egypt but was not suggested due to 'the gravity of the menace' proved that such a 'weighty action in the view of the well-informed', however, it ensured 'the most palatable explanation to the Liberal party and to the general public. ${ }^{24}$ On the other hand, the social and political aspects of the invasion were also two sides of the same coin, namely British imperialism. For instance, Hopkins pointed out that Blunt saw the British occupation of Egypt as 'illustrating a new form of imperialism', which was assigned to Disraeli's alteration of policy and to the enhanced significance of foreign enterprise. ${ }^{25}$ Furthermore, in a letter to Gladstone, Blunt highlighted the humanistic approach as well as international British prestige, 'The English Government has allowed itself to be deceived by its agents, who have cost the country its prestige in Egypt. England will be still worse advised if she attempts to regain what she has lost by the brute force of guns and bayonets. On the other hand there are more humane and friendly means to this end. Egypt is ready still—nay, desirous to come to terms with England, to be fast friends with her, to protect her interests and keep her road to India, to be her ally; but she must keep within the limits of her jurisdiction. ${ }^{26}$ By the same token, Robinson and Gallagher consider the expansion as not of importance because of industrial growth would probably end, but assess it as 'a moral duty to the rest of humanity. ${ }^{27}$ Nonetheless Milner, a liberal journalist and politician, brought comparably a compatible reasoning from other scholars. He justifies British movements as a compulsion on the reason of fast anarchy evolvement than diplomatic acts and Britain did not seek to expand in Egyptian territories. ${ }^{28}$ He further adds that 'Britain saved Egypt from anarchy and all European nations interested in Egypt from incalculable losses in blood and treasure. ${ }^{29}$ Above all, in terms of the reasons for the intervention, it can be summed that British imperialism in Egypt meant an international prestige of the Empire, promoting English honour, safeguarding imperial interests and economic benefits beyond humanitarianism em-

23 Robert Blake, Disraeli, Eyre \& Spotswood, London 1966, p. 583.

24 John S. Galbraith, and Ataf L. al Sayyid-Marsot, 'The British Occupation of Egypt, Another View', International Journal of Middle East Studies, Vol. 9 No. 4, (November, 1978), pp. 471488, p. 473

25 A. G. Hopkins, 'The Victorians and Africa: A reconsideration of the Occupation of Egypt, 1882', Journal of African History, 27, 1986, pp. 363-391 p. 366.

26 Wilfred S. Blunt, A secret History of the British Occupation of Egypt, London 1907, p. 281.

27 Robinson and Gallagher Africa and the Victorians..., p. 2.

28 Alfred Milner, England in Egypt, (London: $5^{\text {th }}$ ed., 1894), p. 16 in Hopkins, Ibid, p. 367.

29 Ibid, p. 14. 
bodied with Christian morality which Gladstonian liberalism was mainly predicated on. In a sketch by John Tenniel in Punch on 30 September 1882, the British Lion has proudly overcome the Egyptian alligator amongst others which also symbolizes British prestige. ${ }^{30}$ More to the point, the Khedive had increasingly been going bankrupt since 1876 whilst the Anglo-French alliance on Egyptian affairs had weakened in 1882. Particularly, a few days before the French President M.Gambetta's resignation signified an alteration of French policy towards Egypt, on the evidence of his letter to the French ambassador, therefore, Newman suggests that 'it was no longer easy to reconcile French policy with that of the British government. ${ }^{31}$ Despite the French reluctance for the British acting alone in Egypt, economic and social issues together with the riots at Alexandria likewise accelerated the invasion. Beyond these reasons, it should also be noted that the intense interest of the British public opinion in foreign policy as it was during the Crimean War and the Eastern question could be counted upon as one of the dynamics which determined the Liberal government's policies. For instance, following the bombardment in Alexandria on 24 July 1882 , the Times reported that liberal papers except the National Gazette were of the opinion that the preparations for an earnest war had already been made to such an extent that public opinion in England would not allow the Cabinet to beat a retreat, but would ask that the action of Turkey should be controlled by English forces. ${ }^{32}$

Undeniably, the outlook of the Liberal ministry and the estimation of Gladstone were in question who had the authority to command British troops and make final decisions regarding subsequent events in the East. In this vein, Robinson and Gallagher point out that Gladstone and the Liberal Ministers had to make a choice between taking an action in terms of imperialism and adhering to election promises made during the Midlothian campaign. Furthermore the authors suggest that all their sentiments, principles and conceptions of the national will and interest determined the liberals to draw back. Yet, in the end, ironically, Robinson and Gallagher point out with Gladstone taking the role of leadership and 'invader.' ${ }^{33}$ On the other hand, Galbraith and al-Sayyid-Marsot claim that all responsibilities belonged to Gladstone and 'no such flagrant illustration of failing memory occurred in the Egyptian crisis but here as well as Gladstone was not in control of the cabinet's decision. ${ }^{34}$ Furthermore, they go far to line up with the convenience of Sir Edward Malet as the British General-Consul in Cairo in the management of the Egyptians with the contribution of Wilfrid Blunt at the end of $1881 .{ }^{35}$ At this point, in the case

30 See Appendices 13. 'The Lion's just share', by John Tenniel, Punch, 30 September 1882,

31 Newman, Great Britain in Egypt..., p. 86.

32 The Times, 28 July 1882.

33 Robinson and Gallagher, Africa and the Victorians, p. 89.

34 Galbraith and al-Sayyid-Marsot., 'The British Occupation of Egypt', p. 478.

35 Ibid, p. 476. 
of the British invasion, it would be hard to define an absolute control of the Prime Minister over the decisions of the parliament. To be precise, the benefit of British imperialism was above the politicians' determination and the case of British occupation of Egypt was one of the unique examples of joint decision of Liberals with Conservatives in the end.

It is therefore important to represent what had changed for Egyptian policy since the Disraeli ministry in the 1870s. Blake defines the British method as 'turning the Sultan and the Khedive into reliable allies rather than seizing their territories. ${ }^{, 36}$ However, the circumstances had changed since the Russo-Turkish War of 18778. Needless to say, the alliance with the Ottoman Empire was interrupted and the opposition attacked Disraeli's foreign politics under the leadership of Gladstone. While the insistence of the Disraeli ministry on the reliance upon British impression of naval forces at Constantinople preceded, it also 'reinforced by a place d'armes in Cyprus, military consuls in Armenia, and the Anglo-French entente. ${ }^{37}$ Blake further identifies Disraeli's aim, therefore, was 'rather to forestall France and prevent a French occupation than to take any step seizing Egypt for Britain. ${ }^{38}$ It becomes clear that Disraeli's 'new imperialism' developed from spontaneous reaction and responses to the opposition. Elridge argues that the empire was 'the visible expression of the power of England in the affairs of the world' ${ }^{39}$ for Disraeli. Robinson and Gallagher take this argument a step further and claims with regards to the consideration of clergy on Disraeli's new imperialism that 'no less than Gladstone and the liberals', they 'were strongly against bringing more Oriental peoples into the empire. ${ }^{40}$ Indeed, this argument may be counted as the distinctive feature of his approach to imperialism. Hopkins also goes so far as to argue that the Conservatives did not plan 'a new Mediterranean strategy or a purposeful new imperialism in the 1870s, and they 'rejected out of hand the idea of occupying Egypt' while the Liberals under Gladstone, were even more reluctant to adopt a forward policy and non-intervention remained the ministry's principle in North Africa throughout in 1881. ${ }^{41}$

Most important of all, the question naturally arises as to the policies and consideration of the head of government. One may argue, therefore, that whilst Gladstone had a personal war with Egypt in terms of his previous opposing statements against imperialism, associated with his election promises during the Midlothian campaign, his responsibilities as Prime Minister on behalf of his party and coun-

\footnotetext{
36 Robinson.and Gallagher, Africa and the Victorian..., p. 77.

37 Ibid, p. 83.

38 Blake, Disraeli, p. 587.

39 C. C. Eldridge, The Imperial Idea in the Age of Gladstone and Disraeli 1868-1880, Macmillan, London 1973, p. 66.

40 Robinson and Gallagher, Africa and the Victorians, p. 85.

41 Ibid, p. 83 and p. 94; Hopkins, 'The Victorians and Africa', pp. 371-372.
} 
try was more prominent. Seen in this light, it would be fair to state that he began shifting his perspective to a certain extent and eventually came up with a solution of amending liberal policies regarding imperialism. Therefore, Gladstone's fame as 'being hostile to imperial expansion', practically turned into compliance 'to the demands of the imperialists within or without his party' at momentous times. ${ }^{42}$ As a witness of his policies at his time, Milner states that 'no one who remembers the character of the British government of that day, or the profound distaste of foreign enterprise which animated the bulk of its followers, the bulk of its followers, can doubt for one moment that Mr. Gladstone's government was sincerely anxious to avoid any fresh interference in the affairs of Egypt, much more the tremendous step of military occupation. ${ }^{43}$ More to the point, Biagini also reaffirmes Matthew's argument that Gladstone 'was not hostile to imperial expansion and in practice he was always a great defender of the British Empire. ${ }^{44}$

In this political atmosphere, there is a clear sense that the criticism of Gladstone's role in British diplomacy against the Ottoman Empire can be gathered under two headings; the antipathy or distrust of Sultan Abdulhamid to the Prime Minister and attacks coming from the opposition on his proposed policy reversing Lord Beaconsfield's Turkish policy. There is little doubt that the suspicions of the Sultan were increasingly high since the beginning of Gladstone's second ministry. On 20 July 1882 it had been reported by the Constantinople correspondent that, 'the Sultan decided the best sequel to the bombardment would be frankly to join England in restoring the status quo ante in Egypt, but the news of partial destruction provoked a violent revulsion of opinion. ${ }^{45}$ The Daily News further gave an extract from the Turkish Vakit gazette by stating, 'the hate that Mr. Gladstone has sworn against us has sufficed to sow misunderstanding and discord between the two great nations on one hand and on the other to deliver over Egypt to fire and sword. ${ }^{46}$ Arguably, this was also the opinion of the majority of the British public. On the other hand, the Essex Standard reported a more general standpoint, 'The known antipathy of the English Premier to the Turks and all things Turkish would have been of itself sufficient to induce the Turkish Ministers to distrust England and English pretentions... this was a situation which places Mr. Gladstone's European statesmanship on a very low level when compared with that all his illustrious predecessors and entire agreement

42 Eugenio Biagini, 'Exporting 'Western \& Beneficent Institutions': Gladstone and Empire, 18801885 ' in David Bebbington and Roger Swift (eds.), Gladstone Centenary Essays, Liverpool University Press, 2000, p. 203.

43 Milner, England in Egypt, p. 13.

44 Biagini, 'Exploring Western' in Bebbington and Swift, Gladstone Centenary, p. 207.

45 'The State of Egypt', Daily News, 20 July 1882, Issue: 11314.

46 Ibid. 
with this disastrous policy developed in Ireland, India and South Africa. ${ }^{47}$ Furthermore, in a meeting of the Patriotic Association, it was stated that the main crisis in Egypt was mainly due to Her Majesty's government. ${ }^{48}$ In a resolution speech, Sir Archibald Campbell stated that 'if Mr. Gladstone's policy of drifting was allowed to go on, his monument would be the ruins of the empire' ${ }^{49}$ whilst Sir A. Bortwick believed 'Mr. Gladstone insulted the Sultan, and as a consequence the national party in Egypt had been allowed to assume their present position. ${ }^{, 50}$

Secondly, reversing Lord Beaconsfield's Ottoman policy which can be seen as the foundation of his Midlothian campaigns of 1879 with pursuing the 'love of freedom with a humanitarian approach in foreign politics' turned into the main criticism affair for the Liberal Government. Nonetheless, it would be fair to state that Gladstone modified his explicit arguments against the Ottoman Empire and Disraeli's Turkish policy. Gladstone occasionally expressed his notion with regards to policy as to the protection of Ottoman territorial integrity and the preservation of the Sultan's situation, 'What I think is the point to which my hon. Friend (Wilfred Wilson) refers is that he considers the maintenance of the Sovereignty of the Sultan in Egypt to be the same thing as the general doctrine of the maintenance of the independence and integrity of the Ottoman Empire. I am not going to say anything upon that general doctrine, either for or against it; but I am going to say this- that with regard to the Sovereignty of the Sultan, in our opinion it ought to be respected when it is not abused - that is a moderate statement - a mild statement - and it is part of our duty to respect it. ${ }^{51}$ The following day, The Times reported that the aim of Ottoman territorial integrity kept him aback against the extraordinary document, namely the ultimatum that Sir Wilfrid Wilson emphasised. ${ }^{52}$ It was further stated that 'the Prime Minister could do anything; whatever he did or said, right or wrong, would be accepted by the country, but personally he declined to be a party to such a policy. ${ }^{53}$ The Derby Mercury also aimed at Gladstone by drawing parallels between conservative ministry, 'Once more the English government finds itself in a condition of serious embarrassment owing to the crisis in the East, brought on in the present instance by Mr. Gladstone's lamentable determination to 'reverse the policy of Lord Beaconsfield'... Lord Beaconsfield saw clearly enough that so long as the integrity of the Ottoman Empire was preserved and the relationship between England and

47 'Liberal Policy in the East', the Essex Standard, 14 January 1882.

48 'England and Egypt- Meeting of the Patriotic Association', The Huddersfield Daily Chronicle, 10 July 1882.

49 Ibid.

50 Ibid.

51 HC Deb 26 May 1882 vol. 269 cc1711-32`Egypt-(Political Affairs) The Existing Crisis-Observations'

52 'London, Saturday, May 27, 1882', the Times, pg. 11; Issue 30518.

53 Ibid. 
the Porte was an amicable one our route to India. This is the policy which has been 'reserved' with a vengeance, and which our blundering Premier now finds himself compelled to adopt after three years' meddling and muddling. ${ }^{54}$

The debates in the British Parliament concerning Egypt between June-July 1882 prior to the bombardment of Alexandria helped to determine the movements of British policy. It would be fair to state that the cabinet was divided between the decisions of a forward policy and an adhesion to the Concert of Europe with French alliance. Robinson and Gallagher suggested that Lord Hartington was concerned on British loneliness opposing French urged to act, 'that he insisted that Britain prepare for the worst: while on the other hand Gladstone and the rest of the cabinet were loathe to consider the possibility of a British expedition. ${ }^{55}$ Nonetheless, it became clear that Urabi Pasha's ${ }^{56}$ independent movements were perceived as the main threat to Egyptian freedom. In that respect, Hopkins argued that Dilke, the Under Secretary of Foreign Affairs, 'began to think of Egypt as a compensation for Britain, and in Julyalmost one year before the bombardment of Alexandria-he formed a committee of like-minded colleagues to monitor Egyptian affairs and to secure a forward policy in opposition to Gladstone's internationalism. ${ }^{57}$ Nonetheless, Sir Edward Malet, as the British Consul-General in Cairo from 1879 to 1883, at the end of his life claimed that 'he had not yet discovered 'the key to the enigma' of the Liberal government's Egyptian policy in I882. ${ }^{58}$ Indeed, there is little doubt that failure of the conference with Sultan Abdulhamid II prior to the Alexandria bombardment also accelerated British military intervention. A week later, John Bright resigned from Gladstone's ministry and declared in a Commons meeting that, 'the simple fact is that I could not agree with my late Colleagues in the Government in their policy with regard to the Egyptian Question... I think that in the present case there has been a manifest violation both of International Law and of the moral law, and therefore it is impossible for me to give my support to it. ${ }^{59}$ Gladstone's response to his resignation ${ }^{60}$ can be considered as peaceful and did not give rise to any opposition in the ministry. Furthermore, the Birmingham Daily Post on 17 July 1882 reported that,'Mr. Bright's resignation has been so long expected and so frequently reported during the past ten days, that its effect on the public mind has to a large extend been discounted. With Mr. Bright's well-known

54 'The Eastern Question', The Derby Mercury, 31 May 1882, Issue: 8733.

55 Robinson and Gallagher, Africa and the Victorians, p. 109.

56 Aḥmad 'Urābī Pasha al-Mișrīi, sometimes referred to as Arabi Pasha or Arabi Bey amongst scholars. For the purpose of this study, hereinafter Urabi Pasha.

57 Hopkins, 'The Victorians and Africa', p. 382.

58 Alexander Scholch, 'The 'Men on the Spot' and the English Occupation of Egypt in 1882', The Historical Journal, Vol. 19, No. 3 ,September, 1976, pp. 773-785, p. 773.

59 HC Deb 17 July 1882 vol. 272 cc722-4,'The Ministry-Resignation of the Right Hon. John Bright'

60 Ibid. 
views on intervention it has been a matter of surprise that he should have remained so long, but his hesitation has, I believe, been due to a natural disinclination to disassociate himself from Mr. Gladstone and to a strong conviction of the honesty and the efficiency of Ministerial policy in Egypt. ${ }^{61}$

There is little doubt that Gladstone's Land Act of 1881 aimed to form equality between the Landlords and tenants, however it was not implemented until the 1885 general election when he converted to Home Rule. While this was considered as a movement towards freedom for Irish people to an extent, the Prime Minister was questioned by his policy in Ireland with a comparison of his policies in Egypt, essentially 'Egypt for the Egyptians'. For instance, Matthew assesses Gladstone's reaction to Egyptian question as 'sympathetic'; through the witness of Wilfrid Scawen Blunt by referring to phrases he had used for Balkan nationalism with a form of criticism which in 1882 'he notably did not use with respect to Ireland. ${ }^{62}$ Throughout the Liberal Ministry, the Irish question was on the principal issues of the Parliamentary debates and the cabinet received strong criticisms from the Opposition regarding the question of imperialism. ${ }^{63}$ From a different angle, Robinson and Gallagher point out that to ministers 'pondering the dangers of democracy, the Irish rifts, the ingrained dislike of expenditure and tropical dependencies, there seemed to be no clear call in British politics for imperial expansion in Africa. ${ }^{64}$ Nevertheless, it becomes clear that a comparison between the question of Ireland and Egypt enabled a differentiation of the meanings of imperialism and political implementation within the circumstances.

While the situation of the national politics is in suspense, it can be argued that external factors were profound in the decision mechanism of foreign policy. Undeniably, the failure of the idea of the Concert of Europe was the mainspring above all. It was Gladstone who defended the essentiality of the unity and collaboration of the great powers in forming Anglo-Ottoman relations. Thus, Yasamee suggests that Britain was pursuing her push on the Concert Policy in the case of Armenian reforms, and points out that there were impressions that Russia was eager to give her full endorsement to in September 1881. ${ }^{65}$ Notwithstanding, it becomes clear that the Prime Minister's confidence and disappointment become evident in the meantime. In a letter to Lord Granville on 12 September 1881 he pointed out that,

"I hope my telegram of last night (tel. 11. September, Austrian consul has telegraphed that the Turks have been applied to by the Khedive for their intervention.

61 The resignation of Mr. Bright', Birmingham Daily Post, 17 July 1882.

62 Matthew, Gladstone, p. 131.

63 'The Country and the Government', the Pall Mall Gazette, 14 July 1882.

64 Robinson and Gallagher, Africa and the Victorians, p. 24.

65 Feroze A. K. Yasamee, Ottoman Diplomacy: Abdulhamid II and the Great Powers, Isis Press, Istanbul 1996, p. 80. 
Rivers Wilson says that a Turkish general carrying an order to the Regiments to be disbanded, would be obeyed, but can we take his word) was intelligible and I am glad to see from a Foreign Office telegram received this morning, that the French seem to attach importance to our steady union \& co-operation in Egypt. This seems to me the main matter, so far as the affairs of that country are concerned, \& I hope they will not think a Turkish General open to the same objections as Turkish troops. I hope also it may not be long before we get a confidential report on the whole transaction."66

Most important of all, it should also be noted that the transition to the policy of Concert of Europe from being the closest Ottoman ally and its implementation during Gladstone's second ministry can be assessed as the main evidence of the alteration of Anglo-Ottoman relations' structure. Up to this point, this research was mainly based on the dynamics and political circumstances around Gladstone that directed his policies and thoughts for the conduct of the new Ottoman foreign policy. It has mainly been argued that the Prime Minister fulfilled the task of imperialism in Egypt as a Prime Minister despite his reluctance and sincerity. This, moreover, bring us to a related question about the occupation of Egypt from the Ottoman perspective. To what extent, was Sultan Abdulhamid II influential in the determination of British foreign policies? And what was Abdulhamid's response to the Egyptian crisis?

First and foremost, the main controversy between the British and Turkish centric point of views is whether Sultan Abdulhamid II offered Egypt to British hegemony and welcomed the occupation. According to an Urabi Pasha's report on 17 June 1882, who led the uprising against the colonisation of Egypt, he was loyal to the Ottoman Caliphate and Sultan but this still caused foreign intervention. ${ }^{67}$ Furthermore, he states that the Ottoman Empire was in favour of peaceful and diplomatic settlements whilst the European powers tried to justify the military occupation. ${ }^{68}$ Matthew pointed out that the Sultan offered Egypt to the British, reserving only his own suzerainty by reflecting the Gladstone diaries and Gladstone's correspondence with his ministers. He further suggested that Gladstone with Granville rejected Abdulhamid II's offer without appealing to the Cabinet. ${ }^{69}$ Although there is no evidence of his assertion, it would be fair to state that the Ottoman Empire later consented to the British occupation instead of Urabi's aggressive manners. ${ }^{70}$ Conversely, Yasamee argues that Abdulhamid's reply to this crisis 'was widely misrepresented by his

66 Ramm, the Political Correspondence of Mr. Gladstone, p. 290.

67 'Urabi Pasa'nin Misir'in siyasi durumu ile ilgili yazisi', Osmanli Belgelerinde Misir, (T.C Basbakanlik Genel Mudurlugu, Osmanli Arsivleri Daire Baskanligi, Yayin nu: 120, 2012), p. 423.

68 Ibid, p. 423.

69 Matthew, Gladstone, p. 133.

70 In an Ottoman report dated 23 September 1882, it was stated that the notables of Cairo welcomed the British invasion and were still waiting for Ottoman help to regulate public order. Ingilizlerin 
contemporaries, and their errors have been copied by later historians. ${ }^{71}$ Particularly he exemplified British and French scholarship by claiming, "there is an assumption that Abdulhamid welcomed Urabi's rebellion. ${ }^{72}$ In doing so, his evidence was the Ottoman documents which he believed 'told a different story: Abdulhamid regarded Urabi and his supporters as 'vermin'; he mistrusted all members of the Khedival family equally and had no marked preference for Halim over Tevfik; and far from wishing to dabble in revolutionary politics, his chief fear was that Britain was using Urabi for revolutionary purposes of her own. ${ }^{73}$

\section{Conclusion}

The main question arises, therefore, the settlement of Egypt and the evaluation of its consequences for Anglo-Ottoman relations. Gladstone summarised the intended British policy, 'Our purpose will be to put down tyranny and to favour law and freedom; and we shall cherish something of the hope that it may yet be given to Egypt, with all her resources, and with the many excellent qualities of her peaceful and peace-loving and laborious people, to achieve in the future, less, perhaps, of glory, but yet possibly more happiness than she did once achieve, when, in far-off and almost forgotten time, she was the wonder of the ancient world. ${ }^{74}$ Undeniably, absolute British control over Egypt would be possible through ensuring a settlement in the military and politics together with social and humanitarian reforms ${ }^{75}$ Nonetheless, this can also be seen as an agreement to abolish of the Sultan's sovereignty over Egypt. It is further stated in the report that 'the sovereignty of the Sultan has wholly failed to fulfil its purposes, and the reestablishment of orderly government against lawlessness and anarchy has been left in the foreign intervention. ${ }^{76}$

In that respect, it becomes clear that the charge against Abdulhamid II was one of the main reasons for the mistrust and breaking the tradition of protecting Ottoman integrity. Following the bombardment in Alexandria, Harper's Weekly published a cartoon in which the British lion and the Turkish Sultan were sketched hugging

Urabi Pasabirliklerini dagitmaya çalistiklari ve idareciler ve askerini isgale karsi direnmedigined air Port Sait muhafizinin raporu', Osmanli Belgelerinde Misir, p. 451.

71 Yasamee, Ottoman diplomacy, p. 87.

72 Ibid.

73 Ibid, p. 88.

74 Hansard, 'Egypt: Gladstone's defence of government policy, House of Commons', 24 July 1882, $3^{\text {rd }}$ series, CCLXXII, cols. 1576-90.

75 'The Settlement of Egypt, the Preliminary Report' in Matthew, Gladstone Diaries, Vol X. ,pp. 3313; Harold Tollepson, Policing Islam, The British Occupation of Egypt and the Anglo-Egyptian Struggle over Control of the Police 1882-1914, Greenwood Press, London 1951.'

76 'The Settlement of Egypt, the Preliminary Report' in Matthew, Gladstone Diaries, Vol X., p. 332. 
each other and bursting into tears. ${ }^{77}$ While this symbolised the old friendship and British relief to the Sultan, it also aimed to depict Abdulhamid as 'insincere' crying his crocodile tears. On the other hand, Biagini points out the contribution of Egytian policies to Gladstonian Liberalism by stating that "having failed to sympathise with secularised Islamic reformer, Gladstone managed to manufacture an ideology of imperial domination which presented Britain's new Egypt policies as consistent with Liberal pledges. ${ }^{, 78}$ Undeniably, Gladstone won a victory with his strongly oppositional foreign policy against the Disraeli ministry during the Eastern Question and now he was on the spotlight with defending British imperialism in Egypt. Elridge addressed the Times article by suggesting that 'imperialism was a word invented to stamp Lord Beaconsfield's supposed designs with popular reprobation... Liberalism was in some sort an antithesis of imperialism. ${ }^{.79}$ It can be argued that Gladstone's Liberal Ministry eliminated this perception. Despite the rising of his sympathisers on imperialism, there is little doubt that Gladstone contradicted his declarations on Liberalism in the meantime. In this vein, the occupation of Egypt turned out to be a personal war for Gladstone's policies with contradictions between his discourse and implementation until the end of his second ministry.

Admittedly, the consideration of Sultan Abdulhamid II for the Liberal Government and particularly the Prime Minister was prudent. Furthermore, the British occupation of Egypt was the utmost of this belief from the Ottoman centric point of view. On the other hand, there is a clear sense that Gladstone endeavoured to emphasise the differences of his politics in opposition between his premierships. Nonetheless, he evidently came across with the ruins of his long lasting and influential politics during the Bulgarian Agitation. Seen in this light, Gladstone's statements on the Egyptian Question can be analysed from two aspects. With hindsight, the Eastern policy he pursued was mainly against the Turkish governors not the Turkish nation and his statements regarding the Ottoman Empire were more sincere when he became Prime Minister. Notwithstanding, it can be argued that Anglo-Ottoman relations was in modification despite the British occupation of Egypt; an Ottoman territory. More to the point, it should also be noted that Lord Granville occasionally stressed that the Government had not departed from the traditional policy of Ottoman territorial integrity which can be seen as he remained the main consultant of the Prime Minister. ${ }^{80}$

Regardless of imperialistic expansionist aims in the Ottoman territories and adopting Palmerston's mantle, Disraeli was nevertheless a supporter of upholding

77 'Alexandria's Bombardment and Burning' by Thomas Nast, 'Harper's Weekly', 22 July 1882. See appendix Figure 15.

78 Biagini, 'Exporting 'Western \& Beneficent Institutions' in Bebbington and Swift (eds.), Gladstone Centenary, p. 216.

79 The Times, 11 March 1880 in Elrdige, Disraeli and the Rise of, p. 70.

80 'London, Wednesday, June 21, 1882', the Times, Jun 21, 1882; pg. 11; Issue 30539. 


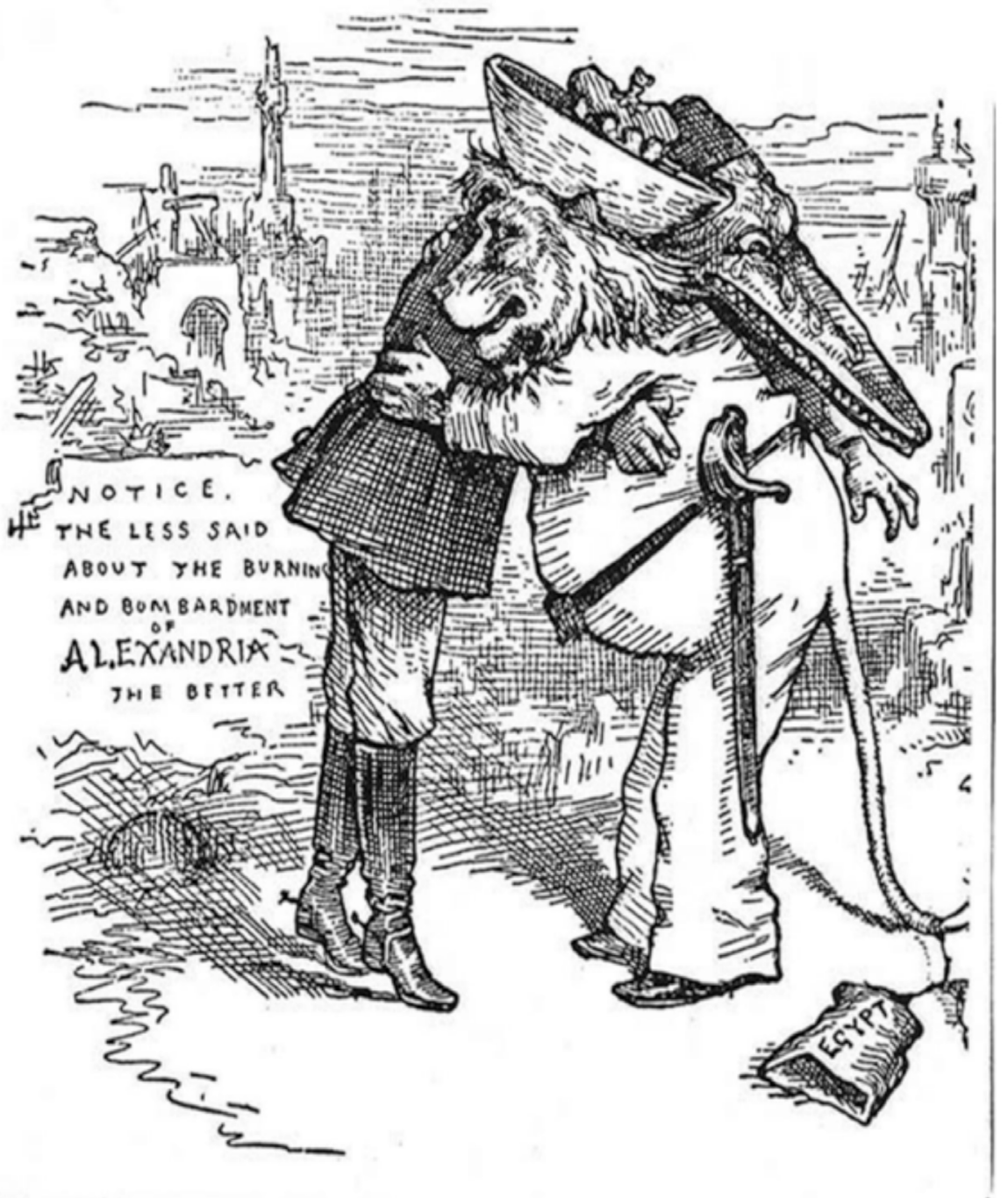

Figure 1. 22 July 1882, Harper's weekly

the integrity of Ottoman Empire in order to safeguard the routes to India and Russian Pan-Slavism. This used to be especially apparent in the case of Egypt. However, this study suggests that the British occupation of Egypt meant a breakaway from the Anglo-French entente with financial control and the end of Gladstone's Concert of Europe foreign policy. Due to political and economic circumstances despite the Liberal Government's reluctant imperialism, Britain had decided to rule Egypt straightforward. The protection of the Suez Canal as well as the interests of 


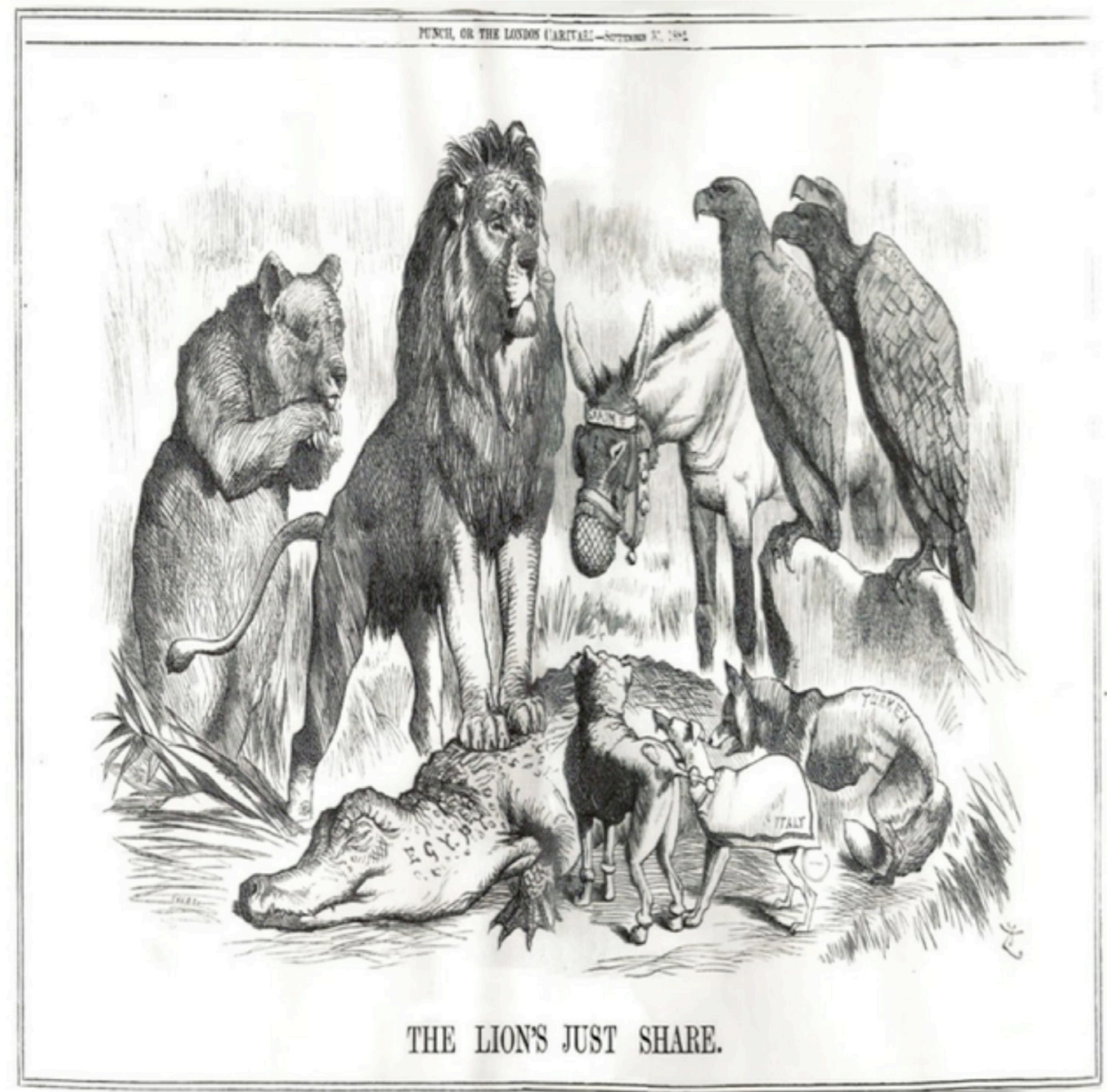

Figure 2. 'The Lion's just Share' 30 September 1882, Punch, and Artist: John Tenniel

the British bondholders and the prestige of the British Empire was vital, which united the Liberal ministry and the Conservatives under Gladstone's umbrella. Despite late Ottoman approval, the occupation signified the edge of Anglo-Ottoman alliance during the nineteenth century. Without question, the occupation was a major experiment for the transition of alleged British liberalism into practical imperialism and the vitality of public opinion in foreign issues since the Eastern Question. In this vein, it would be fair to state that diplomatic relations between the two empires had come to a dead end once again with the occupation. 
Hakem Değerlendirmesi: Dış bağımsız.

Çıkar Çatışması: Yazar çıkar çatışması bildirmemiştir.

Finansal Destek: Yazar bu çalışma için finansal destek almadığını beyan etmiştir.

Peer-review: Externally peer-reviewed.

Conflict of Interest: The author has no conflict of interest to declare.

Financial Disclosure: The auhor declared that this study has received no financial support.

\section{Bibliography}

'Alexandria's Bombardment and Burning' by Thomas Nast, 'Harper's Weekly', 22 July 1882.

'The Lion's just share', by John Tenniel, Punch, 30 September 1882,

Anick, Norman.'The Embassy of Lord Ponsonby to Constantinople 18331841’, Unpublished PhD Thesis, Canada: Montreal University, 1970.

Ata, Ramazan. 'Osmanli kaynaklarina gore 1839-1841 arasi Osmanli-Misir iliskileri ve Duvel-i Muvazzama', 1839-1841 Ottoman Empire and Egypt Affairs and Great Powers under the Light of Ottomans' Sources', Unpublished PhD Thesis, Ankara: Ankara University, 2011.

Atkins, Richard.'The Origins of the Anglo-French Condonium in Egypt, 1875-1876', The Historian, pp. 264-282, 1964.

Biagini, E., 'Exporting 'Western \& Beneficent Institutions': Gladstone and Empire, 1880-1885' in Bebbington, David and Swift, Roger (eds.). Gladstone Centenary Essays, Liverpool University Press, 2000.

Birmingham Daily Post

Blake, Robert. Disraeli, London: Eyre \& Spotswood, 1966.

Blunt, Wilfred S. A Secret History of the British Occupation of Egypt, London, 1907.

Colak, Kamil. 'Misir'in Fransizlar tarafinda isgali ve tahliyesi', SAU Fen-Edebiyat Dergisi, II pp. 141-183, 2008. 


\section{BEGÜM YILDIZELI}

Dennis, Alfred L. P. 'Tendencies in British policy since Disraeli', Proceedings of the American Political Science Association, Vol. 6, Sixth Annual Meeting, pp. 109-120, 1909.

Eldridge, C.C. The Imperial Idea in the Age of Gladstone and Disraeli 18681880, London: Macmillan, 1973.

Galbraith, John S. and Sayyid-Marsot, Ataf L. al 'The British Occupation of Egypt, Another View', International Journal of Middle East Studies, Vol. 9 No. 4, (November, 1978), pp. 471-488.

\section{Hansard Parliamentary Debates}

Hobson, John A. Imperialism: A study, London: James Nisbet \& Co. Limited, 1902.

Hopkins, A. G. 'The Victorians and Africa: A reconsideration of the Occupation of Egypt, 1882', Journal of African History, 27, 1986, pp. 363-391

Ingram, Edward, Eastern Questions in the Nineteenth Century collected essays by Allan Cunningham, vol. II, Great Britain: Frank Cass Co. Lmtd. Publishers, 1993.

Kocaoglu, Mehmet. 'Cavallan Mehmet Ali Pasha 1831-1841', Ankara Üniversitesi Osmanlı Tarihi Araştırma ve Uygulama Merkezi Dergisi, 1994, pp. 209-226.

Lane-Poole, Stanley. The Life of Right Honourable, Viscount Stratford De Redcliffe, Vol II., London: Longmans \& Green and co., 1888.

Matthew, Colin H. G. Gladstone 1875-1898, Oxford: Clarendon Press, 1995.

Matthew, H. C. G., (ed.) The Gladstone Diaries, vol. X, Oxford: Clarendon Press, 1990.

Milner, Alfred. England in Egypt, London: 5th ed., 1888.

Newman, Polson E. W. Great Britain in Egypt, London: Cassell and Company Limited, 1928.

Osmanli Belgelerinde Misir (T.C Basbakanlik Genel Mudurlugu, Osmanli Arsivleri Daire Baskanligi, Yayin nu: 120, 2012.

Polson E. W., Newman. Great Britain in Egypt, London: Cassell and Company Limited, 1928.

Ramm, Agatha (ed.) The Political Correspondence of Mr. Gladstone and Lord Granville 1868-1876, Volume I, Camden Third Series ,London: Royal Historical Society, 1952. 
Ramm, Agatha (ed.) The political correspondence of Mr. Gladstone and Lord Granville 1876-1886, Volume I, 1876-82, Oxford: Clarendon Press, 1962.

Robinson, Ronald and Gallagher, John. Africa and the Victorians the Official Mind of Imperialism, London: Macmillan\& Co. Lmtd., 1965.

Scholch, Alexander,'The 'Men on the Spot' and the English Occupation of Egypt in 1882', The Historical Journal, Vol. 19, No. 3, September 1976, pp. 773785 .

Seton Watson, R. W. Disraeli, Gladstone and the Eastern Question: A Study in Diplomacy and Party Politics, London: Macmillan, 1935.

The Daily News

The Derby Mercury

The Essex Standard,

The Huddersfield Daily Chronicle

The Pall Mall Gazette

The Times

Tollepson, Harold. Policing Islam, The British Occupation of Egypt and the Anglo-Egyptian Struggle over Control of the Police 1882-1914, London: Greenwood Press, 1951.

Yasamee, Feroze A. K. Ottoman Diplomacy: Abdulhamid II and the Great Powers, Istanbul: Isis Press, 1996.

Zeytinli, Emine 'The Effect of Trade Agreements: the case of international trade of Europe and Turkey', Economics and Management, 2012, pp. 1627-1636 